Практичних робіт можна запропонувати достатню кількість, навіть без наявності спеціального астрономічного обладнання, що й планується зробити автором у майбутньому. Виконання практичних робіт й розв'язування задач на заняттях астрономії як у школі, так і у ВНЗ є необхідною умовою для розвитку самостійно мислячої, творчої особистості, здатної зробити власні висновки.

\title{
Література
}

1. Андріївський С. М.Курс загальної астрономії : [навч. посіб.]/ С. М. Андрієвський, І. А. Климишин. - Одеса : Астропринт, 2007. С. 427 -431. 2. Лавут Е. Практичні роботи з астрономії : Гметод. розробка) / Е. Лавут. - Сімферополь : Мала академія наук Криму «Пошукач», 2009. - 31 с. 3. Кузьменков С. Г. Методичні рекомендації та інструкції практичних робіт 3 курсу «Астрономія» / С. Г. Кузьменков, М. О. Бабенко. - Херсон : Херсонський віртуальний університет, 2010.

УДК 351.361

O. С. Мархева, здобувач,

Криворізький педагогічний інститут ДВНЗ «Криворізький начіональний університет»

\section{СТАНДАРТИЗАЦІЯ ПРОФЕСІЙНОЇ ПІДГОТОВКИ ВЧИТЕЛІВ ІНОЗЕМНОЇ МОВИ В КРАЇНАХ ЄВРОПИ}

У статті узагальнено досвід стандартизачії професійної підготовки вчителів іноземної мови у вищих навчальних закладах Німеччини, Швейцарії та Австрії в умовах Болонського процесу. Досліджуються теоретичні засади організації системи професійної підготовки вчителів іноземної мови, навчальні плани провідних вищих навчальних закладів ичих крайн.

Ключові слова: стандартизація, Болонський проиес, професійна підготовка, завдання професійної підготовки вчителів іноземної мови.

В статье обобщается опыт стандартизации профессиональной подготовки учителей иностранного языка в высших учебных заведениях Германии, Швейиарии и Австрии в условиях Болонского процесса. Изучаются теоретические основы профессиональной подготовки учителей иностранного языка, учебные планы ведущуих высших учебных заведений этих стран.

Ключевые слова: стандартизация, Болонский процесс, профессиональная подготовка, задачи профессиональной подготовки учителей иностранного языка.

The article deals with the practice of standardization of the professional training of teachers of foreign languages in higher educational establishments of Germany, Swiss and Austria in the context of the Bologna Process. The theoreti- 
cal bases of the professional training of teachers of foreign languages and curricula of leading higher educational establishments of these countries are studied.

Key words: standardization, the Bologna Process, professional training, the objectives of professional training of teachers of foreign languages.

У контексті глобалізації модернізація освіти означає відкритість світу. Необхідність установлення контактів з університетами інших країн для забезпечення мобільності студентів стає все більш значущою і тим самим піднімається питання про визнання результатів навчання в інших країнах. У зв'язку 3 цим виникає потреба у запровадженні та визнанні спільних навчальних програм, у визнанні ступенів, отриманих в університетах інших країн та континентів, забезпечення якості.

Для активної участі професорсько-викладацького складу вищих педагогічних навчальних закладів України в процесі стандартизації професійної підготовки вчителів іноземної мови в умовах Болонського процесу велике значення має розуміння структури, змісту та організаційних особливостей системи вищої освіти європейських країн і підготовки педагогічних кадрів.

Науковці України активно вивчають досвід країнучасниць Болонського процесу щодо організації системи професійної підготовки вчителів та іiі стандартизації. Питання підготовки вчителів у системі професійної педагогічної освіти в Німеччині досліджують С. Івашньова, Н. Махиня, професійною підготовкою вчителів у сучасній Франції займається Т. Харченко, проблемам професійної підготовки вчителів іноземних мов у Великобританії присвячено праці Н. Авшенюк, В. Базуріної, Ю. Кіщенко, А. Соколової, Н. Яцишина та інших. Найбільш досліджуваним напрямом серед вище згаданих є система професійної підготовки вчителів англомовних країн, у той час як досвіду таких країн, як Австрія, Швейцарія, Німеччина щодо реформування та стандартизації професійної підготовки вчителів іноземної мови в умовах Болонського процесу не приділяється достатньо уваГИ.

Mema cmammi - вивчити досвід стандартизації професійної підготовки вчителів іноземної мови у вищих навчальних закладах Європи в умовах Болонського процесу (на прикладі Німеччини, Швейцарії та Австрії). Для досягнення поставленої мети нами розв'язуються такі завдання: досліджуються теоретичні засади організації системи професійної підготов- 
ки вчителів іноземної мови у вищих навчальних закладах Австрії, Німеччини та Швейцарії; вивчаються навчальні плани провідних вищих навчальних закладів цих країн, в яких здійснюється професійна підготовка майбутніх учителів іноземної мови.

Наш аналіз навчальних планів університетів Австрії, Hiмеччини та Швейцарії дозволив зробити висновок про реалізацію в цих навчальних закладах провідних ідей Болонської декларації. Ця думка підтверджується тим, що в цих країнах, по-перше, вже запроваджено двоступеневу систему підготовки (бакалавр/магістр), яка грунтується на засадах кредитномодульної системи. По-друге, зміст навчальних дисциплін орієнтований на кінцевий результат, а сама професійна підготовка відбувається відповідно до вимог ринку праці. Потретє, кінцеві результати подано як певні професійні та надпредметні компетенції.

Професійна підготовка вчителів іноземної мови у вищих навчальних закладах цих країн становить чотирьохкомпонентну модель, сутність якої полягає у комбінації науково-предметної, дидактичної, виховної та практичної підготовки. Метою такої підготовки $є$ досягнення професійної компетентності вчителя, яка складається 3 таких компонентів: професійна науково-предметна компетентність; дидактична компетентність; педагогічна компетентність; науковоосвітня компетентність; методична компетентність і готовність до роботи в школі. Важливими вважаються також уміння ситуативного моделювання (Situationsdiagnose), рефлексії (Selbstreflexion), соціального аналізу (Gesellschaftsanalyse) [1; 4].

Для досягнення мети професійної підготовки вчителя вищими навчальними закладами (університетами, педагогічними інститутами та академіями) в рамках Болонської декларації вживаються наступні заходи: забезпечується висока якість науково-предметної, загальнонаукової та педагогічної підготовки; теоретична підготовка супроводжується практичною підготовкою, що грунтується на засадах компетентнісного підходу; посилюються міждисциплінарні зв'язки та європейська і міжнаціональна кооперація в царині підготовки вчителів.

Найважливішим завданням підготовки вчителя іноземної мови $є$ формування предметних компетенцій у блоках науко- 
во-предметної та дидактичної підготовки. До таких компетенцій належать:

а) мовні, літературознавчі, культурознавчі та країнознавчі компетенції: фундаментальні знання про структуру мови та іiі історичний розвиток;

б) мовленнєві компетенції (фонетичні, граматичні, стилістичні, лексичні): розуміння та продукція власних письмових та усних текстів, знання мови за професійним спрямуванням (насамперед за економічним напрямком);

в) предметно-дидактичні компетенції: здатність до мотивування тих, хто навчається, застосування та розроблення адекватних методів навчання на основі власних знань; вміння аналізувати підручники, самостійно розробляти навчальні матеріали, використовувати сучасні медії на заняттях, виховувати в учнів толерантне ставлення до інших культур [2; 3]. Ефективність формування вище згаданих компетенцій забезпечується наданням переваги у часовому еквіваленті блоку науково-предметної підготовки. Так, наприклад, в Австрії загальний обсяг навчального навантаження з однієї спеціальності становить 80 семестрових годин, 3 них найбільша кількість годин, а саме 60 відводиться на науково-предметну підготовку, лише 7 годин присвячено науково-педагогічній підготовці і 13 годин дидактичній. Така підготовка доповнюється 12 тижнями педагогічної практики. Значною перевагою австрійської, швейцарської та німецької системи підготовки вчителя іноземної мови, що надає можливість сформувати предметні компетенції на високому рівні $є$ можливість навчання протягом певного періоду часу в країні мови (до 4-х місяців в Австрійських ВНЗ). Важливим є також те, що отримані під час перебування за кордоном кредити зараховуються у ВНЗ цих країн.

Найменший за обсягом годин блок науково-педагогічної підготовки має на меті формування педагогічних компетенцій: дидактичних, психолого-педагогічних, освітньосоціологічних та теоретико-шкільних. Усі ці компетенції сприяють формуванню свідомого і відповідального ставлення майбутнього вчителя до виконання своїх професійних обов'язків із урахуванням вимог до професії вчитель у різних типах шкіл.

Дидактична підготовка відбувається в декілька етапів. На початковому етапі навчання зміст дидактичної підготовки вчителя іноземної мови спрямований на діяльнісно- 
орієнтований підхід, його сконцентровано на шляхи та способи формування в учнів основних компетенцій: лексичної та граматичної, 3 аудіювання, читання, монологічного/діалогічного мовлення, письма та готовності до планування уроків. На просунутому етапі дидактичної підготовки відбувається поглиблення знань, отриманих на початковому етапі. Вивчаються засади використання сучасних медій у навчальному процесі; використання моделей компетенцій для планування навчального процесу та оцінювання навчальних досягнень учнів. На завершальному етапі розвивають методичну компетенцію і доповнюють ії вивченням таких видів навчальної діяльності, як самостійна навчальна діяльність учнів. Усі заняття мають практичне спрямування, центральну роль у їх організації відіграє використання різних форм, засобів і методів навчання. 3 метою отримання всебічної професійної підготовки до роботи в школі майбутні вчителі крім дидактичної підготовки, проходять курс 3 теорії виховання, метою якого $є$ підготовка до роботи з учнівським колективом [2].

Реалізацію принципу практичного спрямування професійної підготовки вчителів іноземної мови в Австрії, Німеччині та Швейцарії забезпечує наявність у навчальному плані такого блоку підготовки, як практична підготовка до роботи в школі. Система організації педагогічної практики майбутніх учителів у вищих навчальних закладах $\epsilon$, на наш погляд, виваженою та послідовною, характеризується поступовим ускладненням завдань та збереженням наступності між окремими етапами. В австрійських ВН3, наприклад, перша фаза практичної підготовки починається 3 третього семестру. Зміст цього етапу практики не є диференційованим залежно від напрямку підготовки майбутніх учителів. Під час семінарських занять, що проводяться в рамках першої фази практичної підготовки, студенти отримують знання про загальні принципи планування і проведення уроків, спостереження за ними та їх оцінювання. Вони також мають можливість попрактикуватись у проведенні окремих сегментів уроків. Із п’ятого семестру починається друга фаза практичної підготовки, вона є диференційованою в залежності від фаху, що вивчають і проходить за обома обраними студентом напрямками, в рівному обсязі (по чотири тижні з кожної дисципліни). Здобуття практичних навичок підкріплюється теоретичним навчанням, яке реалізується через відвідування 
семінарів. На цьому етапі майбутніх учителів іноземної мови також спонукають до самоаналізу, рефлексії набутого досвіду. Цьому сприяє попереднє та завершальне обговорення відвіданих та проведених уроків, підготовка доповіді про проведення практики [3]. У Швейцарії практична підготовка включає вступну практику в першому семестрі, практичні лекції (Übungslektionen) на протязі другого та третього семестрів, проведення практичних занять у четвертому семестрі та взаємовідвідування протягом всіх семестрів (дає можливість отримати цінний досвід проведення занять) [5]. Цікавим є досвід організації практичної підготовки майбутніх учителів іноземної мови в Німеччині. В рамках практичної підготовки на початковому етапі навчання майбутні вчителі іноземної мови проходять орієнтувальну практику (Orientierungspraktikum). У процесі цієї практики відбувається перше ознайомлення зі школою з позиції вчителя, перевіряється власна відповідність обраній професії. Хоча підготовка в німецьких вищих навчальних закладах відбувається для кожного типу шкіл оремо, орієнтувальну практику можна пройти в різних типах, 3 метою отримання загального уявлення про всю систему шкільної підготовки і вибору найбільш прийнятного для майбутнього вчителя типу школи. При цьому термін перебування в кожній школі не повинен бути меншим за один тиждень. Загалом цей тип практики триває 3-4 тижні, iii можна пройти ще до початку навчання або в час, вільний від занять, протягом першого семестру у формі щотижневих відвідувань кількох шкільних уроків 3 наступним обговоренням їх під керівництвом викладача. Обов'язковою умовою допуску до першого державного іспиту $є$ проходження виробничої практики протягом 8 тижнів. Цю практику майбутні вчителі іноземної мови повинні пройти в сфері виробництва, переробки, обслуговування, торгівлі. Можливе також іiі проходження за кордоном. Метою цієї практики є створення в студентів уявлення про ринок праці поза шкільною системою. Цю практику потрібно пройти до початку основного навчального процесу у вищому навчальному закладі. На нашу думку, ці два типи практики сприяють більш виваженому прийняттю рішення щодо своєї професійної відповідності та допомагають формуванню в майбутніх учителів іноземної мови більш свідомого ставлення до обраної професії. Наступним кроком у практичній підготовці бакалавра $є$ шкільна педагогічна практика. Метою цієї практи- 
ки є спостереження за навчальними та соціальними стосунками учнів; за стилем викладання та виховним впливом учителів на учнів; ознайомлення 3 основними проблемами викладання та виховання; підготовка і аналіз занять та власні спроби проведення уроків. Наприкінці цієї практики студентів знов спонукають до підбиття підсумку про власну відповідність обраній професії. Ще одним різновидом шкільної практики є дидактична практика (3 тижні). Завдання, що стоять перед майбутніми вчителями іноземної мови поступово ускладнюються, адже на цьому етапі вони знайомляться 3 навчальними планами, його цілями та завданнями; за заняттями спостерігають 3 метою аналізу різних методичних прийомів та на предмет використання різних типів медій та способів контролю навчальних досягнень учнів; аналізують виховне значення предмета та труднощі, що виникають в школярів під час його вивчення; готовлять, проводять та аналізують власні заняття. Останній тип практики - це дидактична практика без відриву від навчання. Її проходять протягом одного семестру, відвідуючи 1 раз на тиждень чотири години шкільних занять, враховуючи їх обговорення. Основні завдання цієї практики - ознайомлення з методами викладання для різних вікових груп; проведення та аналіз власних уроків [2].

На увагу заслуговують також і форми контролю, що застосовуються навчальними закладами після завершення шкільної практики: так, звітною формою в Швейцарії $є$ ведення журналу практики; в Німеччині результати проходження педагогічної практики майбутній учитель іноземної мови оформлює у вигляді презентації, загальна тривалість якої не повинна бути меншою ніж 20 хвилин. Також надаються записи і транскрипції окремих етапів уроків, фото, копії учнівських робіт. Така форма контролю, на нашу думку, дає можливість навчальному закладу більш об'єктивно оцінити рівень здобутих студентом практичних умінь, сприяє розвитку рефлексивних та аналітичних умінь студентів.

Позитивним моментом у підготовці вчителя іноземної мови $\epsilon$, на нашу думку, іiі спрямованість на формування в студентів свідомого ставлення до навчання та формування вміння аналізувати та критично ставитись до результатів власної навчальної та професійної діяльності. Досягненню високих результатів у цьому напрямку сприяє серед інших i така обов'язкова звітна форма роботи, як ведення портфоліо. 
Портфоліо створюється студентом самостійно і має на меті опис та підтвердження власного шляху навчання та наукової діяльності (він містить звіти з педагогічної практики; роботи, що виконувались студентом під час навчання у повному обсязі або їх частини, можливо на електронних носіях). Крім репрезентативної функції портфоліо, який фактично показує шлях становлення фахівця (його потрібно надати екзаменатору перед другим державним іспитом), він також сприяе рефлексивному аналізу досвіду, набутого студентом під час професійної підготовки. Завдяки веденню портфоліо досягається міждисциплінарність навчання, створюється цілісне уявлення про підготовленість майбутніх учителів іноземної мови до професійної педагогічної діяльності.

Заслуговує на увагу практика університетів Швейцарії та Німеччини щодо використання Інтернет-платформ 3 метою підтримки навчального процесу. Так, наприклад, в університеті Цюриха створено центр координації Інтернет-навчання, метою якого є підтримка викладачів при організації навчання в Інтернет і студентів при використанні електронного ресурсу. Розробники такої Інтернет-платформи наголошують на тому, що дистанційне навчання через Інтернет не може замінити класичних форм організації навчання, а лише доповнює їx, розширює їх можливості завдяки презентації знань у вигляді різних символічних систем і залученню відразу декількох каналів сприйняття інформації. Так, центр координації Інтернет-навчання в університеті Цюріха пропонує наступні основні форми навчання в мережі:

1) розміщення в мережі адміністративної й організаційної інформації та доповідей студентів;

2) електронні елементи самостійного навчання: самостійне опрацювання навчальних матеріалів через Інтернет, виконання тестів, екзаменаційні елементи;

3) комунікація та кооперація в мережі: дискусійні форуми, в якості асинхронної комунікації; чат, як синхронна комунікація; спільне створення текстів (Wiki); відеоконференції; теле-лекції; наставництво Online; E-Mail; Online-семінари [5].

До суттєвих переваг системи організації професійної підготовки майбутніх учителів іноземної мови в досліджуваних нами країнах належить, на нашу думку, поступове ускладнення форм організації навчального процесу та відповідно до них завдань, що ставляться перед майбутніми учителями на 
різних етапах навчання. Так, на початковому етапі основною організаційною формою є лекція, метою якої $є$ презентація центральних тем та методів навчального напрямку; дослідження напрацювань різних учених щодо предмета дослідження, вивчення сучасного стану досліджуваного напрямку. Просемінар, як більш складна форма організації навчального процесу, що вимагає певного рівня сформованості уявлень про предмет дослідження та має на меті надання знань про специфіку наукової роботи, розв'язання фахових проблем шляхом написання рефератів, виконання письмових робіт та ведення дискусій $є$ перехідним етапом від лекції до семінару. Семінар розрахований на студентів, що мають високий рівень теоретичних знань 3 предмета та вже підготовлені до самостійної пошукової наукової діяльності, результатом якої повинна стати письмова семінарська робота. Одним з основних критеріїв успішного опанування професією і формування творчої особистості випускника вищої педагогічної школи в названих країнах $\epsilon$ науково-дослідна робота. Першочерговим завданням науково-дослідної діяльності майбутніх учителів іноземної мови $є$ розвиток уміння аналізувати наукову інформацію; виконувати індивідуальну і колективну науководослідну роботу, спрямовану на отримання нових знань та формування навичок до самоосвітньої діяльності [2].

Проведений нами аналіз дав можливість виявити ряд суттєвих позитивних моментів у системі професійної підготовки вчителів іноземної мови в Німеччині, Австрії та Швейцарії. Науковий обмін між різними країнами, на нашу думку, може дати поштовх до вироблення єдиних підходів щодо організації професійної підготовки вчителів іноземної мови відповідно до подальшої фахової діяльності та створити умови для входження української системи освіти до єдиного європейського освітнього простору з урахуванням позитивного вітчизняного досвіду, що відповідає принципам Болонського процесу.

\section{Література}

1. Byram M. (2003). Teacher education - visions from/in Europe. Babylonia 3-4, 7-10. 2. Ludwig-Maximilian-Universität. Muenchen. Lehrerbildun gszentrum. - [Електронний pecypc]. - Режим доступу:www. unimuenchen.de/lehre_studium/faq/praktika/index.html. 3. Pädagogische Hochschule Wien Curriculum für das Bachelorstudium Lehramt an Hauptschulen. - [Електронний pecypc]. - Режим доступу:http://www.phwien.ac.at/fileadmin/phvie/users/3/pdf/mitteilun gsblatt/curricula/APS/Curriculum_HS_2008-09StuKo_01maerz2009.pdf 
4. Schneider G. Fremdsprachenforschung und die Ausbildung von Fremdsprachenlehrerinnen und -lehrern / Beiträge zur Lehrerbildung, 25 (2). - 2007. - S. 143-155. - [Електронний ресурс]. - Режим доступу: http://www.bzl-online.ch 5. Universität Zürich. E-Learning Koordination der Philosophischen Fakultät. Grundformen der E-Learning. - [Електронний pecypc]. - Режим доступу: www.phil.uzh.ch/ fakultaet/elearning/definition/Grundfomen_von_El.pdf ДВНЗ «Криворізький національний університет»

\section{ПСИХОЛОГО-ПЕДАГОГІЧНІ ОСНОВИ ВИЗНАЧЕННЯ ЗМІСТУ І СТРУКТУРИ ПЕДАГОГІЧНОГО ТЕСТУ}

Статтю присвячено узагальненню основних психолого-педагогічних підходів до визначення змісту і структури педагогічного тесту. Наведено класифікацію основних форм тестових завдань як структурної одиниці тесту. Розглянуто переваги та недоліки тестових завдань, а також формальні, статистичні й психолого-педагогічні вимоги щодо їх включення до складу педагогічного тесту.

Ключові слова: педагогічний тест, завдання в тестовій формі, тестове завдання, завдання відкритого типу, завдання закритого типу.

Статья посвящена обобщению основных психолого-педагогических подходов к определению содержания и структуры педагогического теста. Приведена классификация основных форм тестовых заданий как структурной единиць теста. Рассмотрень преимущества и недостатки тестовых заданий, а также формальные, статистические и психологопедагогические требования по их включению в состав педагогического mecma.

Ключевые слова: педагогический тест, задание в тестовой форме, тестовое задание, задания открытого типа, задания закрытого типа.

The article is dedicated to the generalization of the main psychopedagogical approaches to the determination of the pedagogical test content and structure. The classification of test questions main types as a test structural unit is supplied. The merits and demerits of test questions and also formal, statistical and psycho-pedagogical requirements for their inclusion to the pedagogical test content are considered.

Key words: pedagogical test, test-like questions, test question, essay question, objective question.

В умовах модернізації змісту сучасної системи вищої освіти України застосування тестування як засобу педагогіч- 